\title{
THEORETICAL AND PRACTICAL CRITERIA FOR THE SELECTION OF ECOSYSTEM MONITORING PLOTS IN SWISS FORESTS
}

\author{
JOHN L. INNES \\ Swiss Federal Institute for Forest, Snow and Landscape Research, CH-8903 Birmensdorf, \\ Switzerland
}

(Received: January 1995; revised: April 1995)

\begin{abstract}
A great deal of attention has been paid to the selection of nature reserves. These are important from a conservation viewpoint but, for long-term evaluations, it is important to monitor ecosystems. The need for long-term monitoring plots has been recognized for some time in forest ecology. Of the natural ecosystems, forests are some of the most difficult to monitor because of the time-scales involved in the life-spans of the dominant organisms $(100 \rightarrow 1000$ years). The selection of long-term forest ecosystem monitoring plots is a critical process involving decisions that need to remain valid for many years. Traditional sampling theory suggests that some form of systematic or random sampling may be appropriate, but this is usually inappropriate for the selection of ecosystem monitoring plots. Instead, the selection of plots more closely resembles some of the procedures that are used in the selection of nature reserves. In Switzerland, a monitoring programme has been established which uses a number of criteria for the selection of sites. These include site homogeneity, the abundance and sensitivity of the plant communities to change and the presence of pre-existing data series or monitoring equipment. In addition, the human factor is incorporated by selecting sites from throughout the country, with the willingness of the local forest managers to help with the project being an important factor influencing the final choice of plots. In contrast to most inventories, statistical representativeness is not a requirement for the programme, as the plots are treated as a series of case studies.
\end{abstract}

\section{Introduction}

The long-term monitoring of forest ecosystems has aroused considerable interest (cf. Peterken, 1993), to the extent of generating international legislation (for example, Regulation EC 1091/94 of the European Union: ... 'to help Member States to conduct intensive, continuous surveillance of forestry ecosystems'). Although long-term monitoring studies in forests have been running for some considerable time (over 175 years at a site at Bremerhus in Denmark), the renewed interest that has developed has not extended to the critical aspect of the selection of longterm forest ecosystem monitoring plots. This contrasts both with the literature on general environmental monitoring (e.g. Messer et al., 1991; Wiersma et al., 1984, 1991; Wiersma and Otis, 1986; Hicks and Brydges, 1994; Stevens 1994) and, more markedly, with the large literature on the evaluation of sites for nature conservation. Much of this latter literature has been reviewed by Margules and Usher (1981) and Spellerberg (1992). The nature conservation literature deals with the selection of criteria that can be used to define priorities when deciding which sites should be included within a network of protected ecosystems. Such criteria include 
biodiversity, the rareness of the species within the area, size, naturalness and the threat of human intervention. Many of the techniques that have been developed are relatively sophisticated, such as the environmental representativeness method of Belbin (1993), minimum set methods (Kirkpatrick, 1983; Margules et al., 1988), guild-richness (McKenzie et al., 1989), omission or gap analysis (Burley, 1988; Scott et al., 1991) and gradient analyses (DeVelice et al., 1988; Faith and Norris, 1989). A review of these methods is given by Belbin (1993).

While some of the criteria used for nature reserve design and selection are relevant to the selection of long-term forest ecosystem monitoring sites, it is clear that in many cases rather different priorities need to be used for monitoring sites (which may or may not lie in protected areas) than for protected sites. Of course, some overlap occurs since protected sites are often chosen for long-term monitoring activities. However, monitoring sites also need to be established outside natural and semi-natural areas, particularly if the influence of humans on the future development of man-made ecosystems (most forest ecosystems in Europe) is to be determined. In addition, ecosystems influenced by humans are now the norm in areas such as Europe and North America and the exclusion of such ecosystems from a monitoring programme would result in large areas of important habitat being excluded from long-term monitoring.

A frequently-cited criterion for establishing monitoring sites is that the sites should be located in areas for which data already exist. It is attractive in the short-term to develop long-term monitoring at such sites, as time series can be produced with relative ease and the benefits of long-term monitoring can be easily demonstrated. However, it is important to ensure that any sites are set up in areas that will fulfill the aims of the monitoring programme. It may be necessary to resist political or financial pressure to obtain short-term results if the collection of these is incompatible with longer-term aims. Consequently, new monitoring sites may have to be established while, at the same time, ensuring that the maximum use can be made of existing data sets. The initial period is an important phase of any monitoring programme, and should be viewed as a pilot phase. Consequently, very limited results should be expected during the trial period. However, at the same time, some results may be obtained relatively quickly, particularly if the past history of the stand is being included in the investigations.

Monitoring, in one form or another, has been undertaken in forests for many years. Methods for looking at forest-environment interactions are well-established with early examples of such studies including Cajander (1909), Coile (1935), Kittredge (1948), Smith and Kerr (1956), Zahner (1958), Daubenmire (1959), Bakuzis and Hansen (1960), Stoeckeler (1960) and Weck (1960). These earlier studies provide a useful framework for the current investigation, as they point to some of the more important relationships and processes that need to be monitored. In addition to these earlier studies, a number of recent papers have dealt with studies initiated 30 or more years ago (e.g. Avery et al., 1978; Inghe and Tamm, 1985; Hallbäcken and Tamm, 1986; Foster, 1988; Peterken and Backmeroff, 1988). Shorter-term 
monitoring studies have also provided important information (e.g. Hough, 1965; Sulser, 1971; Abrell and Jackson, 1977; Peet, 1984; Kuhn et al., 1987), and the scientific value of long-term monitoring seems to be without doubt.

In Switzerland, problems have arisen with the interpretation of data from forest sites established to monitor long-term growth trends (Keller, 1994a, b). In particular, the lack of homogeneity in some plots led to systematic differences in growth rates of trees within the plots and difficulties in the development of yield estimates. The problems can be attributed to an inadequate knowledge of ecosystem processes at the time of the initial plot selection and similar problems undoubtedly exist elsewhere. With the increasing emphasis on the multiple use of forests, it seems probable that ecosystem monitoring plots will ultimately replace a proportion of the existing forest growth monitoring plots, and the problems arising from the selection of the latter should not be repeated. The available empirical and theoretical knowledge about ecosystem processes should be fully utilized when selecting future plots. At the same time, a clear reasoning needs to be established for plot selection so that present and future managers can understand why particular sites were chosen.

In this paper, the criteria that have been used to select long-term forest ecosystem monitoring sites in Switzerland are described. Although specifically oriented towards the Swiss programme, the type of plots (more than) meets the requirements of the various European and other initiatives currently being discussed or already implemented. Inevitably, such criteria represent a compromise between what is scientifically desirable, what is practical in the field and what is possible given a finite budget. However, this is the reality facing the majority of project managers today (Schmoldt et al., 1994) and feasibility is increasingly being cited as a requirement when considering both criteria and indicators in monitoring. The ecosystem monitoring program is a part of the national Forest Investigation Programme, which is run cooperatively by the Swiss Federal Forest Service and the Swiss Federal Institute for Forest, Snow and Landscape Research.

\section{Aims of the Programme}

The primary aim of the programme is to identify and evaluate changes in the structure and function of selected forest ecosystems in Switzerland, and an important role of the project is to provide a basis for the development and implementation of the practice of sustainable management of forest ecosystems in Switzerland. Bourgeron and Jensen (1993) argued that the process of formulating sustainable management guidelines should be guided by the following themes:

1. Management goals should be defined precisely.

2. Ecological hierarchies should be defined according to management goals. For example, patterns in forests may be viewed hierarchically from a single plant (e.g. a tree in the canopy) to a community (e.g. a forest-plant community) to 
the biome level (e.g. boreal forests), and these patterns would be characterized by the relevant ecological factors generating the patterns.

3. Ecological patterns and diversity should be understood in terms of processes and constraints generating them, as well as in terms of their possible impact on other components of ecosystems.

4. The implications of management practices on patterns and processes should be understood at all appropriate scales of the hierarchies.

5. Management for sustainability of ecological patterns, processes, and diversity must include maintenance of ecosystem attributes across their natural range of spatial and temporal scales.

6. Sustainable management of ecosystems must be concerned with the sustainability of patterns and processes together, rather than merely the maintenance of existing patterns.

7. The historical range of variablity across a range of spatial and temporal scales must be defined if patterns and processes are to be maintained at all appropriate scales of organisation (e.g. ecological, evolutionary and cultural).

8. Monitoring schemes should be designed that explicitly recognize the hierarchical nature of ecological systems. Monitoring multiple attributes at all appropriate ecological scales can provide a basis to assess ecosystem change.

In the Swiss programme, particular emphasis is being given to the anthropogenic forcing factors that might disrupt the long-term sustainability of forest ecosystems, such as air pollution and climate change, and to more general problems such as landscape dynamics and the visual and ecological impact of different silvicultural practices (Innes, 1994). The programme will provide some of the data required to determine the impact of specific silvicultural systems and changes in site conditions on forested ecosystems and will also provide a framework within which controlled ecosystem management experiments and observations can be undertaken. The programme has an additional function in providing a means by which progress towards the goal of sustained ecosystem management is assessed, but many of these policy goals remain rather poorly formulated.

The emerging emphasis in forestry is on pattern and process in forest landscapes, based on a detailed understanding of the ecology of these landscapes. This is not a new theme and it has been adressed by ecologists for many years (e.g. Watt, 1919, 1924-25, 1947; Jones, 1945; Bormann and Likens, 1979). However, from the point of view of the forest manager, there are certain questions that need to be addressed before deciding on the ecological management objectives, one of the key issues today. Oliver et al. (1993) list these as:

- What is the range of variation in patterns, processes, and species population sizes that the manager wishes to achieve? The spatial and temporal aspects of these ranges need to be described so managers will know whether to favour or discourage certain patterns, processes and species. This cannot be done without a knowledge of natural variability within specific forest ecosystems. 
Some of this information is available in the historical literature, but it is patchy and incomplete.

- How can management practices take into account all patterns, processes and species, especially when they are not all known? If too many things are managed for, then the abilities of the managers will be overloaded.

- How can societal values be determined and incorporated into ecosystem management, especially if these values are changing, and it is not certain how biologically achievable these values are?

- How can patterns, processes and species balances actually be achieved through time and across the landscape? The ability to manage the various changes and project the consequences of action and inaction through time and space needs to be coordinated more closely than has historically been possible.

Some of these questions are as applicable to the nature reserve manager as to the manager of a productive forest. The questions all require detailed information on the patterns and processes in forest ecosystems. Whilst some of this information is currently available, it is scattered throughout the literature and comes from a variety of different ecosystem types. The project described in this paper seeks to utilize this historical information so far as possible, together with large volume of 'grey' literature that exists in a partially published form. Over the next decades, the project will collect a variety of data that can be used to feed into models of long-term sustainability. In addition, a number of site-specific or ecosystemspecific questions will be addressed, further contributing to the rapidly growing understanding of forest ecosystems.

It is clear that the programme must satisfy a number of different requirements, and this creates difficulties when setting priorities for the selection of plots. For example, a project solely aimed at looking at management activities would be heavily biased towards managed forests, and trends in semi-natural forest ecosystems could be missed. However, scientific aspects of the project have been given priority over the use of plots to assess whether specific regulatory aims are being achieved (compliance monitoring - Shaw et al., 1993) and other functions. In particular, the project is aimed at documenting the state of forest ecosystems at successive points in time and in monitoring those processes which are most likely to be responsible for any change in state at a site. In addition, the programme aims to link observations of specific forest ecosystems to ecosystems process modelling, such that predictions can be made concerning the likely future impact of pollutants (e.g. Rihm, 1994) or different climatic conditions (e.g. Kräuchi, 1994). The different states primarily comprise the abundance, health and distribution of selected species within the plots whereas the processes concern the ecological flows which determine changes in these states, such as succession, nutrient cycling and energy flows (Naveh and Liebemann, 1993).

The different requirements for the programme could be analysed formally through an analytic hierarchy process (Anselin et al., 1989; Schmoldt et al., 1994), but the fluidity of the policy requirements mitigates against this. Consequently, the 
balance that has been achieved in the specification of the programme objectives reflects partly the policy requirements at the time the project goals were specified and partly a best-estimate of what are likely to become the main issues of concern over the next years. The latter are of course speculative.

\section{Criteria and Indicators}

A number of different criteria have been recommended for monitoring the sustainable management of forest. The list given below was developed at an expert meeting, the CSCE Workshop on the Sustainable Management of Temperate and Boreal Forests, in Montreal, October 1993 (Schlaepfer et al., 1994). The list should not be seen as fixed and intensive discussions continue about the criteria that should be assessed. For example, in some lists of criteria, ecosystem productivity has been replaced by forest area, reflecting the political interest in deforestation (and afforestation) in some countries.

\subsubsection{Social Criteria}

- Recognition of the multiple functions and uses of forests.

- Recognition of and respect for local community rights and knowledge, history and archaeological sites.

- Provision of institutions and infrastructure for forests.

- Long-term supply of social benefits.

- Long-term output of multiple economic benefits.

\subsubsection{Ecological Criteria}

- Biodiversity (species and landscape).

- Productivity (of the entire ecosystem).

- Soil protection.

- Water protection.

- Forest ecosystem health and vitality, including ecosystem functioning.

- Contribution to global ecological cycles.

In most cases, a range of possible indicators exist for assessing these criteria, although with the socio-economic citeria considerable difficulties may exist in defining measurable indicators. At present, the Swiss monitoring programme is oriented towards the ecological criteria; socio-economic criteria may be incorporated at a later stage in the programme. Indicators, which are generally seen as being more flexible than the criteria, have not yet been evaluated for all criteria. However, it is already clear that the assessment of some indicators may involve destructive sampling incompatible with long-term studies. To enable such sampling, a sufficient plot size, combined with the presence of an adequate buffer zone, is essential.

The selection of indicators represents a difficult area which is outside the scope of this paper, since the choice of indicator plays relatively little role in the choice of 
monitoring plot (although it does affect, for example, plot size). To a certain extent, the choice of indicator is limited by the association of the Swiss programme with two pre-existing monitoring programmes run by the UNEconomic Commission for Europe ('Integrated Monitoring of Ecosystems' and 'Assessment and Monitoring of Air Pollution Effects on Forests'). Both of these programmes have indicator catalogues (Anon, 1993, 1994) although they are surprisingly inconsistent and patchy in their coverage. Many indicators still have to be developed (e.g. for several different types and levels of biodiversity), and this is being undertaken by the international scientific community at the present time. As such indicators become validated, the most relevant will be incorporated into the monitoring programme. The choice of these will naturally depend on the relevance of the indicators to the criteria being monitored, together with the assessment of the cost, practicality and ease of incorporation into the overall programme.

\section{Plot Selection and Plot Stability}

One of the most fundamental concepts involved with monitoring is to determine the stability of the ecosystems under investigation, both under the influence of existing forcing factors and the potential influence of future stresses. In this context, stability is seen as the permanence of a particular forest ecosystem over an area that takes into account small-scale fluctuations due to patch dynamics. Forest ecosystems are subject to external forces, and their ability to resist these forces is receiving increasing attention. For example, critical loads of atmospheric deposition are currently being defined and used to determine pollution control policies (e.g. Rihm, 1994). Although interpretations differ, the critical load concept is related to the amount deposition that an ecosystem can accept without any damage to its most sensitive component. Within the context of forests, this is generally considered to be related to the buffering capacity of the soil (e.g. De Vries, 1988), but this reflects more what can be readily assessed than the actual ecological processes involved (Innes, 1992). Clearly, the ability of an ecosystem to maintain its organization when exposed to disturbance (i.e. the concept of integrity) needs to be monitored and more than one ecosystem characteristic is required to do this.

While it is frequently assumed that there is a direct connection between the stability and diversity of particular ecosystems (e.g. Ashton, 1969; van der Maarel, 1993), this assumption has been questioned on a number of occasions (e.g. Paine, 1966; MacArthur, 1971; May, 1972; Allen and Starr, 1982) and biodiversity cannot be used alone as an indicator. The problem appears to be more related to the connections between different components within the ecosystem than to diversity per se (O'Neil et al., 1986) and the degree and nature of the connectivity between different elements within the system appears to be important. This in turn implies that to establish the integrity of an ecosystem, assessments are required of both the different elements present and their connections. The use of only one or two 
indicators was a fundamental error made in forest health monitoring in the $1980 \mathrm{~s}$ and is only now being rectified. Ecosystems need to be considered at a variety of spatial and temporal scales (O'Neil et al., 1986), especially when looking at ecosystem integrity. This point is examined further below.

Stability was considered by Burrows (1990) to consist of four aspects: persistence, inertia, resilience and constancy. These involved the long-term continuity of the species assemblages within an ecosystem and their resistance to change. They can in part be assessed by repeated inventories, but this provides relatively little information about the processes responsible for any observed changes. A variety of techniques can be used to assess each, but it is important not to consider each in isolation. Ecosystem integrity is a holistic concept and needs to be considered as such. In particular, changes within the entire system need to be determined; in forest, changes may occur for example in the ground flora without any perceptible change in the dominant organisms in the ecosystem, the trees. However, longterm monitoring to date has revealed that forests are liable to change, even those considered to be a relatively stable state (e.g. Peterken and Jones, 1987).

\section{Criteria for Plot Selection Within Switzerland}

Specialized procedures are necessary for the selection of plots because the nature of ecological data often prevents the application of classical statistical approaches, particularly when the natural pattern of a variable is non-random. Unless the sampling density is very high (which is impractical in detailed ecosystem monitoring studies), random or systematic placement of samples sites will not accurately reflect the full range of variability of the biotic and abiotic components of the ecosystems at regional scales. Interpolation and extrapolation from non-random sampling designs also present problems, but predictive statistical models can be used to generate quantitative relations between species or communities and environmental factors using location-specific data sets. In addition, the use of geographic information systems will greatly facilitate the interpretation of point-related and regional data. Consequently, despite the problems of bias, a subjective sampling design appears to be the most useful, provided that it is controlled as rigorously as possible. As outlined before, each (subjective) decision can be based on the available knowledge of forest ecosystems.

Within Switzerland, the network of monitoring plots is designed to ensure that the sites cover a range of different forest types, based on floristic composition, and are relevant to current concerns. This was achieved by locating plots in the most common biogeoclimatic units identified in the country, with a weighting being given towards the sensitivity of these units to change (due to air pollution and climate change). Although the units have still to be formally mapped over most of Switzerland, some knowledge already exists of their relative abundance, together with limited quantitative information (Ellenberg and Klötzli, 1972; Schmider $e t$ al., 
1993; Kull, 1994). At the time of plot establishment, no information was available on the representativeness of the plots at a local scale.

\subsection{SITE TYPES}

Although there is an increasing amount of information available on the quantitative analysis of resource use by animals (e.g. Manly et al., 1993), most quantitative assessments of the conservation value of sites have concentrated on plants. For example, Dony and Denholm (1985) looked at woodland plant communities and assessed (a) the total number of species present, (b) the proportion of species that were rare or locally common and (c) an index ignoring common species and weighted towards those rarest in the region as a whole. Such a process cannot be applied to the choice of site types in Switzerland as quantitative data on the extent of different site types within the country are, as already indicated, unavailable.

A wide range of different forest site types is present in Switzerland (see Ellenberg and Klötzli 1992 for a full account). The Ellenberg and Klötzli classification is similar to biogeoclimatic classifications developed, for example, in Canada (e.g. Jones et al., 1983). With 71 site types recognized in Switzerland by Ellenberg and Klötzli (1972), it would be financially impossible to locate plots in all site types and, at the same time, have sufficient replication within types to enable useful analyses of the data. Consequently, priorities (on a scale of one to three) were established on the basis of the putative importance of the site types in Switzerland and their predicted susceptibility to change (Table I). These priorities were based on the estimated abundance of each site type and their sensitivity to indirect disturbance by anthropogenic activities. For example, although the Larici-Pinetum cembrae type is restricted in its distribution, it represents a high-altitude ecosystem that is potentially susceptible to alteration as a result of climate change. Very rare site types were excluded on the grounds that these are being covered by specialized monitoring undertaken by conservation organizations.

The level of division used in the site type classification is obviously of importance. It would be possible to further sub-divide all the site types such that even more rigid communities were delineated, as for example done by Schmider $e t$ al. (1993). However, the adopted classification represents a (subjective) compromise between different levels of classification. This division also has important implications for the degree of heterogeneity of sites. A considerable level of micro-scale variation may be present within plots, but this is accepted provided that the site type remains the same. This decision is rather arbitrary given the nature of the site type classification, but reflects the need to be practical within the scientific constraints that have been developed.

It is important to recognize that the site types listed in Table I are not actual vegetation types. Rather, they reflect the potential vegetation which it is believed would occur in the absence of any human interference. Consequently, it is possible to have for example a Milio-Fagetum site type that currently has a stand of Picea 


\section{TABLE I}

Site types included in the choice of long-term monitoring plots in Switzerland. The classification follows that of Ellenberg and Klötzli (1972). Abundance refers to the supposed occurrence of particular forest types in Switzerland and sensitivity to their likelihood to change. The prioritization was developed by Walther Keller, Bertil Krusi, Peter Kull, Nino Kuhn and Thomas Wohlgemuth.

\begin{tabular}{|c|c|c|c|}
\hline & & Abundance & Sensitivity \\
\hline \multicolumn{4}{|c|}{ Top priority } \\
\hline 1.1 & Galio odorati-Fagetum typicum & 1 & 1 \\
\hline 1.2 & Milio-Fagetum & 1 & 1 \\
\hline 1.3 & Galio-odorati-Fagetum luzuletosum & 1 & 1 \\
\hline 2.1 & Veronico latifoliae-Piceetum & 1 & 2 \\
\hline 2.2 & Sphagno-Piceetum typicum & 1 & 2 \\
\hline 2.3 & Sphagno-Piceetum calamagrostietosum villosae & 1 & 2 \\
\hline 3.1 & Larici-Pinetum cembrae & 2 & 1 \\
\hline 4.1 & Calamagrostio villosae-Abietetum & 1 & 2 \\
\hline 4.2 & Dryopterido-Abietetum & 1 & 2 \\
\hline 5.1 & Erico-Pinetum silvestris & 2 & 1 \\
\hline \multicolumn{4}{|c|}{ Medium priority } \\
\hline 1.1 & Carici albae-Fagetum typicum & 2 & 2 \\
\hline 1.2 & Luzulo silvaticae-Fagetum typicum & 2 & 2 \\
\hline 2.1 & Bazzanio-Abietetum & 3 & 2 \\
\hline 3.1 & Cardamino-Fagetum typicum & 1 & 3 \\
\hline 3.2 & Cardamino-Fagetum tilietosum & 1 & 3 \\
\hline 4.1 & Mixed Quercus-Betula forest & 2 & 3 \\
\hline 5.1 & Galio silvatici-Carpinetum & 3 & 1 \\
\hline \multicolumn{4}{|c|}{ Lowest priority } \\
\hline 1.1 & Aceri-Fraxinetum & 3 & 3 \\
\hline 1.2 & Ulmo-Fraxinetum listeretosum & 3 & 3 \\
\hline 1.3 & Ulmo-Fraxinetum typicum & 3 & 3 \\
\hline
\end{tabular}

abies growing on it and no Fagus sylvatica. From the perspective of site establishment, the most important aspect of the use of the site types is to have plots located on homogeneous site types and to have a range of different site types represented in the monitoring programme. The presence of a single site type over the whole plot implies a certain uniformity of site conditions which, in turn, will facilitate the 
interpretation of the monitoring data and its incorporation into ecosystem models. The naturalness of any of the stands is questionable given the absence of suitable reference stands in central Europe and any attempt to influence the plot selection on a naturalness criterion would have been liable to error.

The influence of heterogeneity is difficult to determine, particularly as heterogeneity operates at a variety of different scales. For example, the restriction of a sampling plot to one particular community in the Ellenberg and Klötzli classification has a number of advantages, but this classification system is purely concerned with site type. Consequently, the classification fails to take into account factors such as structural heterogeneity. The structural diversity of the plot is particularly important given the effects of forest fragmentation on the physical and biological characteristics of the ecosystem (e.g. Fahrig and Paloheimo, 1988; Opdam, 1991; Chen et al., 1993; Esseen, 1994; Lens and Dhondt, 1994). The presence of a uniform structure was therefore included as an additional criterion for site selection.

The existence of internal edges, the probability of which increases with increasing plot size, may be particularly important (e.g. Harris, 1988). The extent to which such edge effects affect the ecosystem will depend on which aspect of the ecosystem is being considered. An edge effect extending for only $10 \mathrm{~m}$ may be applicable for some tree species (Wales, 1972), but $30 \mathrm{~m}$ is more realistic for many invertebrate species and some bird species may be affected for up to $500 \mathrm{~m}$ from the edge (Wilcove et al., 1986). In the Swiss plots, the presence of a buffer zone of $50 \mathrm{~m}$, extending from the forest edge to the plot edge, was a requirement for the plots (following edge effect studies such as Ranney et al., 1981; Esseen, 1994; and Young and Mitchell, 1994), although the $50 \mathrm{~m}$ could consist of a different forest type and structure. Plot edges were however located a minimum of $10 \mathrm{~m}$ from the site type boundary. This relatively small buffer zone means that some edge effects will certainly be present in the plots (Temple, 1986; Zipperer, 1993), but this was unavoidable given the small-scale nature of Swiss forests. In addition, the borders of plots were located at least $500 \mathrm{~m}$ from major sources of disturbances, such as heavily-used roads.

The effects of some of the micro-scale variation can be established by mapping each plot in detail, with the spatial coordinates of each tree and any other features being recorded. This level of detail is required if factors such as competition and dispersal are to be accounted for (e.g. Mack and Harper, 1977; Czárán and Bartha, 1992; Maxwell and Ghersa, 1992; Perry et al., 1993).

\subsection{NATURE OF THE PLOTS}

\subsubsection{Size}

The size of nature reserves has been the subject of considerable debate, but much of this is related to the conservation of a mosaic of habitats rather than a single homogeneous unit (e.g. Terborgh, 1976; Higgs and Usher, 1980; Forman and Godron, 
1986). Much of this work stems from the literature on the relationship between diversity and sample area (Arrhenius, 1921; Gleason, 1922) and the abundance of species on islands (e.g. Brenner, 1921; Preston, 1962; MacArthur and Wilson, 1963). The principles of island biogeography have been used as an argument that reserves should be as large as possible (Diamond, 1975; Diamond and May, 1976; Shafer, 1990) although the validity of this theory to habitat islands within a landscape is uncertain (e.g. MacArthur and Wilson, 1967; Janzen, 1983). The species-area concept suggests that within a uniform habitat species diversity per unit area should increase with sample area, and there is a great deal of empirical evidence to support this. However, such arguments may be less appropriate when the option exists to establish monitoring points in a variety of patch types spread over a large geographical region, particularly if that region is structurally diverse (Forman, 1981), as in the case of Switzerland. In addition, much of the theory concerns the number of species rather than the composition of the communities (Kadmon and Pulliam, 1993), and the latter may be more important when looking at ecological interactions.

Some observations do not support the idea that a single large area is more useful than several smaller ones, with greater diversity of some organisms being maintained by a series of small, isolated patches (Helliwell, 1976; Simberloff and Abele, 1976, 1982; Dony and Denholm, 1985). A number of other problems exist, particularly in relation to the definition of landscape patch edges (Whittaker, 1973; Harris, 1988) and species turnover rates (Gilbert, 1980). The nature of the mosaic within which the patch lies is critical (Antonovics and Levin, 1980; Addicott $e t$ al., 1987) and the mosaic exerts a strong influence on the species composition and metapopulation dynamics of the patch. These all lead to difficulties in the selection of the size of monitoring plots.

While many long-term ecological monitoring plots are relatively small $(0.25$ ha in the European Union Regulation), a plot of this size may present problems when establishing the nature of long-term ecological processes operating in the plot. In the equilibrium landscape concept, it is assumed that there is a certain degree of persistence and constancy when a parameter is averaged over a sufficiently large area, particularly when disturbances are taken into account (Bormann and Likens, 1979; Shugart, 1984; DeAngelis and Waterhouse, 1987; Turner et al., 1993). In a natural forest consisting of hemlocks and hardwoods and with a disturbance regime dominated by small canopy graps, Busing and White (1993) found that spatial variation of biomass and basal area declined at scales of $>0.5$ ha, but variations in forest composition occurred at scales of $0.5-1$ ha. This strongly suggests that the 0.25 ha plot size is inadequate for some of the more basic studies normally associated with forest ecology and, in this study, a plot size of 2 ha was chosen as the ideal. This was considered to be close to the maximum patch size that could be found in a range of different forest types in Switzerland. A further requirement was that each 2 ha plot should be located within a larger forest area, with a minimum size of 30 ha. 


\subsubsection{Shape}

Where feasible, each plot consists of two areas, consisting of 1 ha each. The shape of these was not a factor in the selection of the plots, although it was recognized that a useful (from a practical viewpoint) shape was $100 \mathrm{~m} \times 100 \mathrm{~m}$. This contrasts with the $4: 1$ length-to-width ratio favoured by some ecologists (e.g. Bormann, 1953), but reduces the potential edge effects that such an extended plot would have (Ranney et al., 1981). In a homogeneous area, the ideal plot would consist of a circle 2 ha in area, with the inner 1 ha consisting of a protected (from destructive sampling) zone and the outer being used for destructive sampling. In Switzerland, it is very rare to find a 2 ha homogeneous area, and the idea of a circular plot has to be dropped. A rectangular design is favoured over a circular design since the latter is much more difficult to demarcate in the field. Instead, the plot shape was allowed to vary according to the nature of the plots, with two 1 ha polygons being used in some cases and a single 2 ha area in others. In all cases, a core area was delimited, where destructive sampling is not permitted (except where this forms a part of normal management operations on managed plots).

\subsubsection{Access}

Year-round access was a requirement, although the use of methods such as snow poles has enabled some assessments to be made remotely. The measurement of parameters such as throughfall chemistry means that regular visits to the plots have to be made throughout the year and, in mountain areas, this factor plays an important part in determining which plots can be included in the network. Financial and topographic limitations meant that the use of radiotelemetry for the downloading of data from the automatic weather stations at each of the plots is not feasible. Although the problem is relatively rare in Switzerland, plots were located in areas where vandalism is unlikely.

\subsection{PRESENCE OF OTHER MONITORING NETWORKS}

Within Switzerland, there is a wide range of different monitoring networks. These include networks for air quality, soil quality, meteorology, phenology, forest growth and others. In addition to the federal networks, a number of cantons run their own monitoring networks related to their specific interests. A first step in the evaluation involved building a GIS database with the locations of the sites of plots in these networks. This was used to identify clusters of environmental monitoring plots where a forest plot might possibly be located.

Plot selection took into account the presence of existing monitoring schemes. Wherever possible, priority was given to locating plots on existing regional monitoring points or in the vicinity of other monitoring stations. A monitoring programme was already in existence in some cantons (Flückiger and Braun, 1994) and, where possible, plots for the new monitoring programme were located on or adjacent to these. Similarly, three research plots from a past national research 
program (NFP 14+) were also given priority in the evaluation, although only one was found to be suitable for a plot and, even then, its inhomogeneity may cause problems in the future.

The blending of the data from older programmes with the information collected by the new programme presents an important challenge. In Switzerland, there are already a large number of single-theme monitoring networks. In some cases, it is possible to utilize these data by relatively simple extrapolations. However, in many cases, the data from one site cannot be extrapolated to another by any simple algorithm. An example is provided by ozone data. The network of rural monitoring stations in Switzerland is relatively sparse and the cost of establishing new stations is such that modelling was deemed the most suitable method of relating values from measurements stations to other sites. However, the complexity of the dynamics of ozone (in horizontal and vertical space and over time) is such that such extrapolations will be extremely difficult, if not impossible. Consequently, alternative methods (e.g. passive samplers) are being explored.

As there is a strong interest in the role of pollution as a stress in Swiss forest ecosystems, the pollution climate of the site was important. Sites were specifically sought in areas known to be subject to high concentrations of ozone or high levels of nitrogen deposition, and also in areas where soils were susceptible to acidification caused by acidic deposition. The co-occurrence of all three of these conditions in the south of the country (Ticino) led to a significant concentration of plots in this area.

\subsection{TECHNICAL ASPECTS}

\subsubsection{Equipment in the Plots}

In each plot, a variety of equipment is being installed. This includes an automatic weather station (located in the nearest large open area), litterfall traps, soil-water sampling equipment and other material. The availability of a suitable space for the weather station together with the possibility of permission for the installation of the station, were criteria for the installation of the plots. An electricity supply was not, however, a criterion as developments in solar energy, the long-life of modern batteries and low electricity requirements of much equipment all mean that a mains supply is not required.

\subsubsection{Management Operations}

Approximately half of the plots are being located in plots without any silvicultural interventions. The remaining half are being located in forests utilized for, amongst other things, wood production. Normal management operations are being permitted in the plots. The only constraint is that management operations undertaken in a plot should only cover half the area (i.e. $1 \mathrm{ha}$ ). In the event of storm damage or a similar problem, normal remedial action over the whole area is permitted. 
The placement of plots in protected forests represents an attempt to establish the characteristics of natural processes operating in forest ecosystems. Unlike other parts of the world, there are no natural ecosystems in Switzerland: all have been influenced to a greater or lesser extent by humans. Consequently, any 'controls' have to be obtained through assessments of forests that are currently unmanaged or through studies of natural forest ecosystems in other parts of the world. The latter approach is complicated by a range of factors such as differences in species composition and climate, but may be the only way in which a realistic idea of the expected condition of a particular forest type can be derived.

\subsubsection{Cooperation with Local Forest Managers}

This is a joint project between scientists, the cantons and forest owners. Assistance was sought from local staff, amounting to 0.5 days every two weeks (i.e. $5 \%$ manyear) for each plot, together with any optional time taken for meetings dealing with information transfer. This time will involve visits to the plots every two weeks to check equipment, download data and to undertake any routine maintenance that is required. Where such assistance was not available but the canton was still eager to have a monitoring plot, a lower level of plot was established, involving only very limited process measurements and no monitoring of climate, precipitation chemistry or other phenomena requiring frequent visits.

\subsubsection{Data Exchange}

All site-specific data are being made available to the cantons and the forest owners. Staff from the Swiss Federal Institute for Forest, Snow and Landscape Research are also available to answer specific questions related to the plots. Copies of all publications arising from the project are available free to the cantons and the forest owners, and methods to provide open remote access to the project databank are being explored.

\subsection{A SCORING SYSTEM FOR SELECTION PRIORITIES}

Various scoring systems have been devised for assessing priorities (e.g Tans, 1974; Ogle, 1981; Bedward et al., 1991). Table II is similar to the table devised for assessing the amenity value of woodlands devised by Helliwell and published in the British Arboricultural Associations' 1990 publication Amenity Valuation of Trees and Woodlands. However, in contrast to the Helliwell system, scores of $>0$ for certain of the factors are a requirement for inclusion in the system. In the table, the minimum score required for a particular criterion is indicated by an asterisk.

The list was used to select plots from a shortlist that was drawn up of sites that met the basic requirements of the selection criteria. A factor involved in this final selection was the geographical distribution of plots within Switzerland, with an attempt being made to ensure an even coverage over the entire country. 
JOHN L. INNES

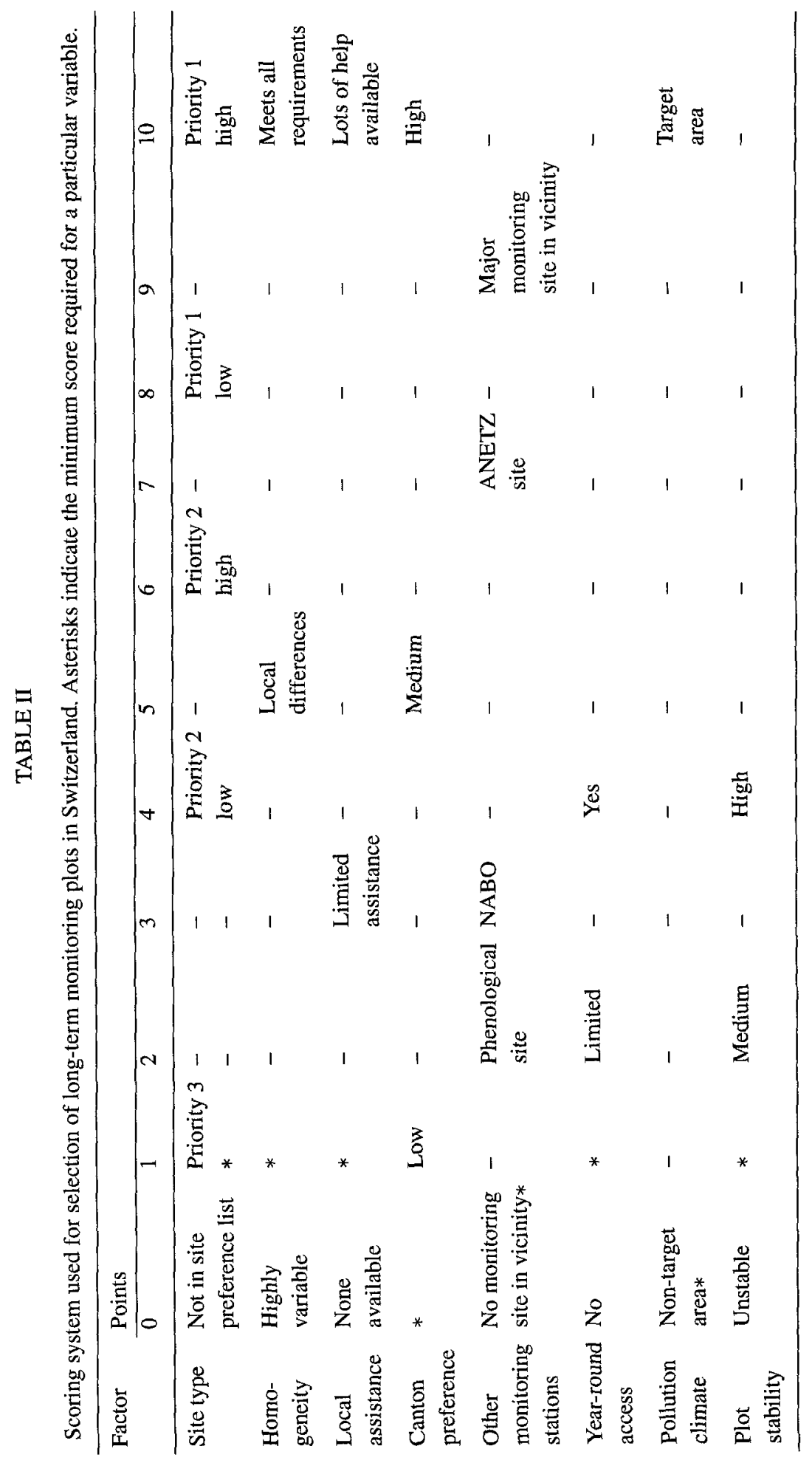




\section{Relationships Between Plots and the Landscape}

An important part of any inventory or monitoring programme is to assess the relationship between the sample plots and the population being assessed. In an inventory, this is normally done through the use of an appropriate sampling design: the data from the plots are considered to be representative of the population. In long-term ecosystem monitoring, a representative network based on a systematic, stratified random or other design may be inappropriate and it is best to view the monitoring plots as a series of independent case studies. Of course, it may be possible to compare data from different plots, particularly if some of the environmental factors are controlled.

As with nature conservation (Hansson and Angelstam, 1991), in monitoring, it is important to know the relationship between the plots and the landscape of which they form a part. The plots can be considered as homogeneous landscape units, but within a particular landscape only one unit may be being assessed. Consequently, it is necessary to extend the observations outside the 2 ha plots. One of the criteria for plot selection in Switzerland is that the plots must be located in an area of forest exceeding $30 \mathrm{ha}$. This is to enable the study of species or other aspects of the ecosystem that occur at a scale larger than 2 ha (e.g. the terriorial ranges of some bird species). Similarly, it is necessary to go outside these 30 ha to understand some of the flows that occur between different landscape units. This is particularly true in Switzerland where steep, long slopes are frequently present, facilitating the transfer of materials from and to individual landscape units. Such a hierarchical approach is already quite well established in some areas of ecology (e.g. O'Neill et al., 1986; Cullinan and Thomas, 1992; Bell et al., 1993; Bourgeron et al., 1993) and has been made relatively easy by tools such as remote sensing and geographic information systems.

Metapopulation analysis is an increasingly important tool when assessing the conservation values of habitats (e.g Andrewartha and Birch, 1954; Levins. 1969; Hanski, 1994) and the principles are of relevance in the current context. In particular, the trends observed in a single plot or area are dependent on the trends occurring elsewhere. A local extinction is clearly of much less significance than one from a larger area, but without some form of monitoring over a larger area, the significance of local changes cannot be adequately assessed (Nisbet and Gurney, 1982). Within the present context, it is important to view the plots as patches within a landscape and to view disturbance to these patches as isolated events, not necessarily affecting other plots within the network (Atmar and Patterson, 1993). In particular, asynchronous disturbances may play an important part in the population dynamics (Sherratt and Jepson, 1993).

The application of metapopulation theory to monitoring plots is complex. At present, the spatial and temporal extent of the plots is linked to specific ecological processes, such as nutrient cycling, stand dynamics and soil processes. The inclusion of a zoological component places the plots within a different spatial and 
temporal window and it remains to been to what extent the two windows can be brought together. The application of techniques such as GIS and remote sensing offers possibilities, but these have still to be fully evaluated within the current programme.

\subsection{STATISTICAL ASPECTS OF THE SAMPLING PROGRAMME}

Several of the problems discussed in the previous section relate to sampling design. When developing an ecosystem monitoring network, it is frequently asked how representativeness will be achieved. This, however, is a value-loaded question. The most obvious problem is to determine what level of representativeness is being sought. The cost of establishing an ecosystem monitoring network is such that it is extremely unlikely that a truly representative network, covering a variety of ecosystem types, will be achieved for any single ecosystem - the variability of single ecosystems is simply too great (e.g. Gersmehl et al., 1982). Similarly, the project is unlikely to be representative of all different types of ecosystems since the range of ecosystem types is too great (depending on the classification used). There is a trade-off here: as the detail at which the ecosystem is defined increases, the within-ecosystem variation decreases. Within the current context, it is not intended that the plots within the programme provide representative data for temperate forest ecosystems or for example a particular community type (e.g. the Luzulo silvaticae - Fagetum forest community). Instead, the plots form a series of case studies that are not designed to provide representative data. The data, amongst other things, will be used to calibrate more general forest development models which will be used to predict the future development of the forest at that site. When the predictions for different site types are similar, then it may be possible to make suitably qualified generalizations, but this is as far as such a process can be taken. This has always been the basis for extending the results derived from case studies (Bailey, 1991).

Within plots, sampling is undertaken using statistically defined procedures. For each indicator, a literature search is undertaken to assess the within-stand variability of that indicator. Where no such data are available, a pilot project has been initiated to determine the required sampling density and temporal frequency. In cases where the required sampling is too costly or the disturbance involved in the sampling is such that it jeopardizes other parts of the programme, the indicator has been dropped or new methods sought. This process is seen as particularly important as, given the limitations imposed by the methods of plot selection, the requirement for objectively defined assessments in the plots is very high.

\section{Conclusions}

The programme here was developed as a joint project between scientists and forest managers with the specific aim of determining the long-term sustainability of Swiss 
forest ecosystems, currently at a risk from a number of anthropogenic stresses. This aim has had a major influence on the design of the project and the choice of monitoring plots. The selection of the sites that will provide the information for assessing long-term sustainability is difficult. Ecological, economic and social factors must all be taken into account. Sites need to satisfy a range of criteria and, even they need to be relevant to the specified objectives of the programme. The criteria presented here were specifically developed for Switzerland, but they are likely to be just as applicable to other countries embarking on long-term monitoring programmes of forest ecosystems. In addition, most nature reserves involve some monitoring and the development of links between the long-term monitoring of productive and protected forests can only be of value to both.

\section{Acknowledgements}

I am grateful to Peter Duelli, Michèle Kaennel, Walter Keller, Norbert Kräuchi, Anne Thimonier and an anonymous referee for helpful comments during the preparation of this maniscript. Extensive feedback from Walter Keller, Erwin Städler and Urs Zehnder on the practical side of plot selection has been extremely useful.

\section{References}

Abrell, D. B. and Jackson, M. T.: 1977, 'A decade of Change in an Old-growth Beech-maple Forest in Indiana', American Midland Naturalist 98, 22-32.

Addicott, J. F., Aho, J. M., Antolin, M. F., Padilla, D. K., Richardson, J. S. and Soluk, D. A.: 1987, 'Ecological Neighbourhoods: Scaling Environmental Patterns' Oikos 49, 340-346.

Allen, T. F. H. and Starr, T. B.: 1982, Hierarchy: Perspectives for Ecological Complexity, University of Chicago Press, Chicago.

Andrewartha, H. G. and Birch, L. C.: 1954, The Distribution and Abundance of Animals, University of Chicago Press, Chicago.

Anon.: 1993, Mannual for Integrated Monitoring. Programme phase 1993-1996, Environmental report 5. Environment Data Centre, National Board of Waters and the Environment, Helsinki.

Anon.: 1994, Manual on Methods and Criteria for Harmonized Sampling, Assessment, Monitoring and Analysis of the Effects of Air Pollution on Forests, Programme Coordinating Centre West, Federal Research Centre for Forestry and Forest Products, Hamburg.

Anselin, A., Meire, P. M. and Anselin, L.: 1989, 'Multicriteria Techniques in Ecological Evaluation; An Example Using the Analytical Hierarchy Process', Biological Conservation 49, 215-229.

Antonovics, J. and Levin, D. A.: 1980, 'The Ecological and Genetic Consequences of Densitydependent Regulation in Plants', Annual Reviews of Ecology and Systematics 11, 411-452.

Arrhenius, O.: 1921, 'Species and Area', Journal of Ecology 9, 95-99.

Ashton, P. S.: 1969, 'Speciation Among Tropical Forest Trees: Some Deductions in the Light of Recent Evidence', Biological Journal of the Linnaean Society 1, 155-196.

Atmar, W. and Patterson, B. D.: 1993, 'The Measure of Order and Disorder in the Distribution of Species in Fragmented Habitat', Oecologia 96, 373-382.

Avery, C. C., Larsen, F. R. and Shubert, G. H.: 1978, Fifty Years of Virgin Stand Development in Southwestern Ponderosa Pine, USDA Department of Agriculture, Forest Service, General Technical Report RM22.

Bailey, R. G.: 1991, 'Design of Ecological Networks for Monitọing Global Change', Environmental Conservation 18, 173-175. 
Bakuzis, E. V. and Hansen, H. L.: 1960, 'Some Relationships Between Vegetational Indication and Broad Soil Groups in Minnesota Forest Communities', Minnesota Forestry Notes 90.

Bedward, M., Pressey, R. L. and Nicholls, A. O.: 1991, 'Scores and Score classes for Evaluating Criteria: A Comparison Based on the Cost of Reserving all Natural Features', Biological Conservation 56, 281-294.

Belbin, L.: 1993, 'Environmental Representativeness: Regional Partitioning and Reserve Selection', Biological Conservation 66, 223-230.

Bell, G., Lechowicz, M. J., Appenzeller, A., Chandler, M., DeBlois, E., Jackson, L., Mackenzie, B., Preziosi, R., Schallenberg, M. and Tinker, N.: 1993, 'The Spatial Structure of the Physical Environment', Oecologia 96, 114-121.

Bormann, F. H.: 1953, 'The Statistical Efficiency of Sample Plot Size and Shape in Forest Ecology', Ecology 34, 474-487.

Bormann, F. H. and Likens, G. E.: 1979, Pattern and Process in a Forested Ecosystem, Springer Verlag, New York.

Bourgeron, P., Humphries, H. C., de Velice, R. L. and Jensen, M. E.: 1993, 'Ecological theory in relation to landscape evaluation and ecosystem characterization', in: Jensen, M.E. and Bourgeron, P. (Eds.), Eastside Forest Ecosystem Health Assessment. Volume II. Ecosystem management: Principles and Application, US Department of Agriculture, National Forest System, Forest Service Research, Washington D.C., pp. 65-80.

Brenner, W.: 1921, 'Växtgeografiska studier i Barösund skärgård', Acta Societas Fauna Flora Fennica 49, 1-151.

Burley, F. W.: 1988, 'Monitoring Biological Diversity for Setting Conservation Priorities', in: Wilson, E. O. (Ed.), Biodiversity, National Academy Press, Washington DC, pp. 227-230.

Burrows, C. J.: 1990, Processes of Vegetation Change, Unwin and Hyman, London.

Busing, R. T, and White, P. S.: 1993, 'Effects of Area on Old-growth Forest Attributes: Implications for the Equilibrium Landscape Concept', Landscape Ecology 8, 119-126.

Cajander, V.: 1909, 'Über Waldtypen', Acta Forestalia Fennica 1, 1-175.

Chen, J., Franklin, J. F. and Spies, T. A.: 1993, 'Contrasting Microclimates Among Clearcut, Edge, and Interior of Old Growth Douglas Fir Forest', Agricultural and Forest Meteorology 63, 219-237.

Coile, T. S.: 1935, 'Relation of Site Index for Shortleaf Pine to Certain Physical Properties of the Soil', Journal of Forestry 33, 726-730.

Cullinan, V. I. and Thomas, J. M.: 1992, 'A Comparison of Quantitative Methods for Examining Landscape Pattern and Scale', Landscape Ecology 7, 211-227.

Czárán, T. and Bartha, S.: 1992, 'Spatiotemporal Dynamic Models of Plant Populations and Communities', Trends in Ecology and Evolution 7, 38-42.

Daubenmire, R. F.: 1959, Plants and Environment, John Wiley, New York.

DeAngelis, D. L. and Waterhouse, J. C. (1987). 'Equilibrium and Nonequilibrium Concepts in Ecological Models', Ecological Monographs 57, 1-21.

DeVelice, R. L., DeVelice, J. W. and Park, G. N.: 1988, 'Gradient Analysis in Nature Reserve Design: A New Zealand Example', Conservation Biology 2, 206-217.

Diamond, J. M.: 1975, 'The Island Dilemma: Lessons of Modern Biogeographic Studies for the Design of Natural Reserves', Biological Conservation 7, 129-146.

Diamond, J. M. and May, R. M.: 1976, 'Island Biogeography and the Design of Natural Reserves', in: R. M. May, (Ed.) Blackwell, Oxford, pp. 163-186.

Dony, J. G. and Denholm, I.: 1985, 'Some Quantitative Methods of Assessing the Conservation Value of Ecologically Similar Sites', Journal of Applied Ecology 22, 229-238.

Ellenberg, H. and Klötzli, F.: 1972, 'Waldgesellschaften und Waldstandorte der Schweiz', Mitteilungen der Schweizerisches Anstalt für forstliches Versuchswesen 48, 587-930.

Esseen, P.-A.: 1994, 'Three Mortality Patterns After Experimental Fragmentation of an Old-Growth Conifer Forest', Biological Conservation 68, 19-28.

Fahrig, L. and Paloheimo, J.: 1988, 'Effect of Spatial Arrangement of Habitat Patches on Local Population Size', Ecology 69, 468-475.

Faith, D. P. and Norris, R. H.: 1989, 'Correlation of Environmental Variables with Patterns of Distribution and Abundance of Common and Rare Freshwater Macroinvertebrates', Biological Conservation 50, 77-98. 
Flückiger, W. and Braun, S.: 1994, Waldschaden-Bericht. Untersuchungen in Beobachtungsflächen 1984-1993, Institut für Angewandte Pflanzenbiologie, Schönenbuch.

Forman, R. T. T.: 1981, 'Interactions Among Landscape Elements: A Core of Landscape Ecology', in: Tjallingii, S. P. and de Veer, A. A. (Eds.) Perspectives in Landscape Ecology, Centre for Agricultural Production and Documentation, Wageningen, pp. 35-48.

Forman, R. T. T. and Godron, M.: 1986, Landscape Ecology, John Wiley, New York.

Foster, D. R. (1988). 'Species and Stand Response to Catastrophic Wind in Central New England, U.S.A.', Journal of Ecology 76, 135-151.

Gersmehl, P., Napton, D. and Luther, J.: 1982, 'The Spatial Transferability of Resource Interpretations', in: Proc. National In-Place Resource Inventories Workshop (9-14 August 1981, University of Maine, Orono, Maine), Society of American Foresters, Washington DC, pp. 402-405.

Gilbert, L. E.: 1980, 'The Equilibrium Theory of Island Biogeography: Fact or Fiction?', Journal of Biogeography 7, 209-235.

Gleason, H. A.: 1922, 'On the Relation between Species and Area', Ecology 3, 158-162.

Hallbäcken, L. and Tamm, C. O.: 1986, 'Changes in Soil Acidity from 1927 to 1982-1984 in a Forest Area of South-west Sweden', Scandinavian Journal of Forest Research 1, 219-232.

Hanski, I.: 1994, 'A Practical Model of Metapopulation Dynamics' Journal of Animal Ecology 63, 151-162.

Hansson, L. and Angelstam, P.: 1991, 'Landscape Ecology as a Theoretical Basis for Nature Conservation', Landscape Ecology 5, 191-201.

Harris, L. D.: 1988, 'Edge Effects and the Conservation of Biotic Diversity', Conservation Biology $2,330-332$.

Harris, H. J., Milligan, M. S. and Fewless, G. A.: 1983, 'Diversity: Quantification and Ecological Evaluation in Freshwater Marshes', Biological Conservation 27, 99-110.

Helliwell, D. R.: 1976, 'The Effects of Size and Isolation on the Conservation Value of Wooded Sites in Britain', Journal of Biogeography 3, 407-416.

Hicks, B. B. and Brydges, T. G.: 1994, ‘A Strategy for Integrated Monitoring', Environmental Management 18, 1-12.

Higgs, A. J. and Usher, M. B.: 1980, 'Should Nature Reserves be Large or Small?', Nature 285, $568-569$.

Hough, A. F.: 1965, 'A twenty-year Record of Understory Vegetational Charge in a Virgin Pennsylvania Forest', Ecology 46, 370-373.

Inghe, O. and Tamm, C. O.: 1985, 'Survival and Flowering of Perennial Herbs. IV. The behaviour of Hepatica nobilis and Sanicula europaea on Permanent Plots During 1943-1981', Oikos 45, $400-420$.

Innes, J. L.: 1992, 'Stress Combinations in Forests', in: Schneider, T. (Ed.) Acidification Research: Evaluation and Policy Application, Elsevier, Amsterdam, pp. 87-96.

Innes, J. L.: 1994, 'Design of an Intensive Monitoring System for Swiss Forests', in: Beniston, M. (Ed.) Mountain Environments in Changing Climates, Routledge, London, pp. 281-300.

Janzen, D. H.: 1983, 'No Park is an Island: Increase in Interference From Outside as Park Size Decreases', Oikos 42, 402-10.

Jones, E. W.: 1945, 'The Structure and Reproduction of the Virgin Forest of the North Temperate Zone', New Phytologist 44, 130-148.

Jones, R. K., Pierpoint, G., Wickware, G. M., Jeglum, J. K., Arnup, R. W. and Bowles, J. M.: 1983, Field Guide to Forest Ecosystem Classification for the Clay Belt, Site Region $3 e$. Maple, Ontario.

Kadmon, R. and Pulliam, H. R.: 1993, 'Island Biogeography: Effect of Geographical Isolation on Species Composition', Ecology 74, 977-981.

Keller, W.: 1994a, Standörtliche Inhomogenität von ertragskundlichen Versuchsflächen - eine Ursache von Fehlschlüssen? Deutscher Verband Forstlicher Forschungsanstalten, Sektion Ertragskunde. Jahrestahung vom 16-18 May 1994, pp. 153-159.

Keller, W.: 1994b, 'Standörtliche Inhomogenität von ertragskundlichen Versuchsflächen - eine Ursache von Fehlschlüssen?' Schweizerische Zeitschrift für Forstwesen 145, 1031-38.

Kirkpatrick, J. B.: 1983, 'An Iterative Method for Establishing Priorities for the Selection of Nature Reserves: An Example from Tasmania', Biological Conservation 25, 127-134.

Kittredge, J.: 1948, Forest Influences, McGraw-Hill, New York. 
Kräuchi, N.: 1994, 'Modelling Forest Succession as Influenced by a Changing Environment', Mitteilungen der Eidgenössischen Forschungsanstalt für Wald, Schnee und Landschaft 69, 145-271.

Kuhn, N., Amiet, R. and Hufschmid, N.: 1987, 'Veränderungen in der Waldvegetation der Schweiz infolge Nährstoffanreicherungen aus der Atmosphäre', Allgemeine Forst- und Jagdzeitung 158, $77-84$.

Kull, P.: 1994, 'Vegetationsaufnahmen', in: Sanasilva-Waldzustandbericht 1993. Der Zustand des Schweizer Waldes, Berichte der Eidgenössischen Forschungsanstalt für Wald, Schnee und Landschaft 339, 40-41.

Lens, L. and Dhondt, A. A.: 1994, 'Effects of Habitat Fragmentation in the Timing of Crested Tit Parus cristatus Natal Dispersal', Ibis 136, 147-152.

Levins, R.: 1969, 'Some Demographic and Genetic Consequences of Environmental Heterogeneity for Biological Control', Bulletin of the Entomological Society of America 15, 237-240.

MacArthur, R. H.: 1971, 'Patterns of Terrestrial Bird Communities', Farner, D. S. and King, J. R. (Eds.) Academic Press, New York, pp. 189-221.

MacArthur, R. H. and Wilson, E. O.: 1963, 'An Equilibrium Theory of Insular Zoogeography,' Evolution 17, 373-387.

MacArthur, R. H. and Wilson, E. O.: 1967, The Theory of Island Biogeography, Princeton University Press, Princeton, New Jersey.

McKenzie, N. L., Belbin, L., Margules, C. R. and Keighery, G. J.: 1989, 'Selecting Representative Reserves Systems in Remote Areas: A Case Study in the Nullarbor Region, Australia', Biological Conservation 50, 239-261.

van der Maarel, E.: 1993, 'Some Remarks on Disturbance and its Relations to Diversity and Stability', Journal of Vegetation Science 4, 733-736.

Mack, R. N. and Harper, J. L.: 1977, 'Interference in Dune Annuals: Spatial Pattern and Neighbourhood Effects', Journal of Ecology 65, 345-363.

Manly, B., McDonald, L. and Thomas, D.: 1993, Resource Selection by Animals. Statistical Design and Analysis for Field Studies, Chapman and Hall, London.

Margules, C. R., Nicholls, A. O. and Pressey, R. L.: 1988, 'Selecting Networks of Reserves to Maximize Biological Diversity', Biological Conservation 43, 63-76.

Margules, C. and Usher, M. B.: 1981, 'Criteria Used in Assessing Wildlife Conservation Potential: A Review', Biological Conservation 21, 79-109.

Maxwell, B. D. and Ghersa, C.: 1992, "The Influence of Weed Seed Dispersion Versus the Effect of Competition on Crop Yield', Weed Technology 6, 196-204.

May, R. M.: 1972, 'Will a Large Complex System be Stable?', Nature 238, 413-414.

Messer, J. J., Linthurst, R. A. and Overton, W. S.: 1991, 'An EPA Program for Monitoring Ecological Status and Trends', Environmental Monitoring and Assessment 17, 67-78.

Naveh, Z. and Liebemann, A.: 1993, Landscape Ecology, Springer Verlag, New York.

Nisbet, R. M. and Gurney, W. S. C.: 1982, Modelling Populations, John Wiley and Sons, New York.

Ogle, C. C.: 1981, 'The Ranking of Wildlife Habitats', New Zealand Journal of Ecology 4, 115-123.

O'Neill, R. V., DeAngelis, D. L., Waide, J. B. and Allen, T. F. H.: 1986, A Hierarchical Concept of Ecosystems, Monographs in Population Biology 23, Princeton University Press, Princeton.

Oliver, C. D., Knapp, W. H. and Everett, R.: 1993, 'A System for Implementing Ecosystem Management', in: Jensen, M. E. and Bourgeron, P. S. (Eds.) Eastside Forest Ecosystem Health Assessment. Vol. II. Ecosystem Management: Principles and Applications. U.S. Department of Agriculture, National Forest System, Forest Service Research, pp. 377-388.

Opdam, P.: 1991, 'Metapopulation Theory and Habitat Fragmentation: A Review of Holarctic Breeding Bird Studies', Landscape Ecology 5, 93-106.

Paine, R. T.: 1966, 'Food Web Complexity and Species Diversity', American Naturalist 100, 65-75.

Peet, R. K.: 1984, 'Twenty-six Years of Change in a Pinus strobus - Acer saccharum Forest, Lake Itasca, Minnesota, Bulletin of the Torrey Botanical Club 111, 61-68.

Perry, J. N. and Gonzalez-Andujar, J. L.: 1993, 'Dispersal in a Metapopulation Neighbourhood Model of an Annual Plant with a Seedbank', Journal of Ecology 81, 453-463.

Peterken, G. F.: 1993, 'Long-term Studies in Forest Reserves, in: Broekmeywer, M. E. A., Vos, W. and Koop, H. Pudoc, (Eds.) European Forest Reserves, Wageningen, pp. 35-48. 
Peterken, G. F. and Backmeroff, C. E.: 1988, Long-term Monitoring in Unmanaged Woodland Nature Reserves, Research and Survey in Nature Conservation 9, Nature Conservancy Council, Peterborough.

Peterken, G. F. and Jones, E. W.: 1987, 'Forty Years of Change in Lady Park Wood: The Old-Growth Stands', Journal of Ecology 75, 477-512.

Preston, F. W.: 1962, 'The Canonical Distribution of Commonness and Rarity', Ecology 43, 185-215 and 410-432.

Ranney, J. W., Bruner, M. C. and Levenson, J. B.: 1981, 'The Importance of Edge in the Dynamics and Structure of Forest Islands', in: Burgess, R. L. and Sharp, D. M. (Eds.) Forest Island Dynamics in Man-Dominated Landscapes, Springer-Verlag, New York, pp. 677-96.

Rihm, B.: 1994, Critical Loads of Acidity for Forest Soils and Alpine Lakes. Steady State Mass Balance Method, Federal Office of Environment, Forests and Landscape, Switzerland, Environmental Series no. 234. BUWAL, Bern.

Schlaepfer,R., Innes, J. L., Stewart, R. and Langevin, F.: 1994, 'Workshop on Environmental Criteria/Indicators for the Sustainable Development of Boreal and Temperate Forests', in: Seminar of Experts on Sustainable Development of Boreal and Temperate Forests, September 27 to October 1 1993, Montreal, Canada. Technical Report, Annex 1. Natural Resources Canada, Ottawa, pp. $13-21$.

Schmider, P., Küper, M., Tschander, B. and Käser, B.: 1993, Die Waldstandorte im Kanton Zürich, Verlag der Fachvereine an den schweizerischen Hochschulen und Techniken AG, Zürich.

Schmoldt, D. L., Peterson, D. L. and Silsbee, D. G.: 1994, 'Developing Inventory and Monitoring Programs Based on Multiple Objectives', Environmental Management 118, 707-727.

Scott, J. M., Csuti, B. and Davis, F.: 1991, 'Gap Analysis: An Application of Geographic Information Systems for Wildlife Species', in: Decker, D. J., Kransy, M. E., Goff, G. R., Smith, C. R. and Goss, D. W. (Eds.) Challenges to the Conservation of Biological Resources, Westview Press, Boulder, Colorado, pp. 167-179.

Shafer, C. L.: 1990, Nature Reserves. Island Theory and Conservation in Practice, Smithsonian Institution Press, Washington DC.

Shaw, D., Greenleaf, J. and Berg, D.: 1993, 'Monitoring New Forestry', Environmental Monitoring and Assessment 26, 187-193.

Sherratt, T. N. and Jepson, P. C.: 1993, 'A Metapopulation Approach to Modelling the Longterm Impact of Herbicides on Invertebrates', Journal of Applied Ecology 30, 696-705.

Shugart, H. H.: 1984, A Theory of Forest Dynamics, Springer-Verlag, New York.

Simberloff, D. S. and Abele, L. G.: 1976, 'Island Biogeographic Theory and Conservation Practice', Science 191, 285-286.

Smith, J. H. G. and Kerr, J. W.: 1956, 'Some Problems and Approaches in Classification of Site in Juvenile Stands of Douglas-fir', Forestry Chronicle 32, 418-428.

Spellerberg, I. F.: 1992, Evaluation and Assessment for Conservation, Chapman and Hall, London.

Stevens, D. L.: 1994, 'Implementation of a National Monitoring Program', Journal of Environmental Management 42, 1-29.

Stoeckeler, J. H.: 1960, 'Soil Factors Affecting the Growth of Quaking Aspen Forests in the Lake States', Minnesota Agricultural Experimental Station Technical Bulletin 233.

Sulser, J. S.: 1971, 'Twenty Years of Change in the Hutcheson Memorial Forest', William L. Hutcheson Memorial Forest Bulletin 2, 15-24.

Tans, W.: 1974, 'Priority Ranking of Biotic Natural Areas', Michigan Botanist 13, 31-39.

Temple, S. A.: 1986, 'Predicting Impacts of Habitat Fragmentation on Forest Birds: A Comparison of Two Models', in: Verner, J., Morrison, M. L. and Ralph, C. J. (Eds.) Wildlife 2000: Modeling Habitat Relationships of Terrestrial Vertebrates, University of Wisconsin Press, Madison, pp. 301-304.

Terborgh, J.: 1976, 'Island Biogeography and Conservation: Strategy and Limitations', Science 193, 1029-1030.

Turner, M. G., Romme, W. H., Gardner, R. H., O’Neill, R. V. and Kratz, T. K.: 1993, 'A Revised Concept of Landscape Equilibrium: Distance and Stability on Scaled Landscapes', Landscape Ecology 8, 213-227. 
De Vries, W.: 1988, 'Critical Deposition Level for Nitrogen and Sulphur on Dutch Forest Ecosystems', Water, Air and Soil Pollution 42, 221-239.

Wales, B. A.: 1972, 'Vegetation Analysis of North and South Edges in a Mature Oak-Hickory Forest', Ecological Monographs 42, 451-471.

Watt, A. S.: 1919, 'On the Causes of Failure of Natural Regeneration in Britsh Oakwoods', Journal of Ecology 7, 173-203.

Watt, A. S.: 1924-25, 'On the Ecology of British Beechwoods With Special Reference to Their Regeneration. Part II. The Development and Structure of Beech Comminities on the Sussex Downs', Journal of Ecology 12, 145-204; 13, 27-73.

Watt, A. S.: 1947, 'Pattern and Process in the Plant Community', Journal of Ecology 35, 1-22.

Weck, J.: 1960, 'Klimaindex und forstliches Produktionspotential. Ein weiterer Beitrag zum Problem ihrer Korrelation', Forstarchiv 31, 101-105.

Wiersma, G. B., Frank, C. W., Case, M. J. and Crockett, A. B.: 1984, 'The Use of Simple Kinetic Models to Help Design Environmental Monitoring Systems', Environmental Monitoring and Assessment 4, 233-255.

Wiersma, G. B. and Otis, M. D.: 1986, 'Multimedia Design Principles Applied to the Development of the Global Baseline Integrated Monitoring Network', in: Cohen, Y. D. (Ed.), Pollutants in a Multimedia Environment, Plenum Press, New York. pp. 317-332.

Wiersma, G. B., Otis, M. D. and White, G. J.: 1991, 'Application of Simple Models to the Design of Environmental Monitoring Systems: A Remote Site Test Case', Journal of Environmental Management 32, 81-92.

Wilcove, D. S., McLellan, C. H. and Dobson, A. P.: 1986, 'Habitat Fragmentation in the Temperature Zone'. in: Soulé, M. E. (Eds.) Conservation Biology: The Science of Scarcity and Diversity, Sinauer Associates, Sunderland, pp. 237-256.

Young. A. and Mitchell, N.: 1994, 'Microclimate and Vegetation Edge Effects in a Fragmented Podocarp-Broadleaf Forest in New Zealand', Biological Conservation 67, 63-72.

Zahner, R.: 1958, 'Site-quality Relationships of Pine Forest in Southern Arkansas and Northern Louisiana', Forest Science 4, 163-176.

Zipperer, W. C.: 1993, 'Deforestation Patterns and Their Effects on Forest Patches', Landscape Ecology 8, 177-184. 